\title{
PERLINDUNGAN HUKUM PADA PEMBERIAN LISENSI BAGI PEMULIA VARIETAS TANAMAN
}

\author{
Fernando Simanjuntak $^{1}$, Etty Susilowati ${ }^{2}$
}

\begin{abstract}
Abstrak
Pemulia tanaman menghasilkan varietas baru tanaman merupakan salah satu bagian dari Hak Kekayaan Intelektual (HKI) dan diatur sesuai dengan hukum Indonesia yang bertitik tolak dari ketentuan GATT/WTO. Hasil dari pemuliaan tanaman diatur oleh Undang-Undang Nomor 29 Tahun 2000 tentang Perlindungan Varietas Tanaman. Undang-Undang tersebut memberikan perlindungan hukum kepada pemulia tanaman dan varietas tanaman. Salah satu perlindungan hukum yang dijamin oleh Undang-Undang Perlindungan Varietas Tanaman adalah pemanfaatan nilai ekonomi dari hak pemulia atas varietas tanaman yang dihasilkannya melalui lisensi. Lisensi yang diberikan berupa izin untuk menggunakan seluruh atau sebagian dari hak Perlindungan Varietas tanaman kepada orang atau badan hukum lain meskipun pemulia tanaman bukan merupakan pemegang hak PVT atau peneliti pada lembaga pemerintah. Rumusan masalah yang dapat dikemukakan dalam penelitian ini adalah: (1) Bagaimana mekanisme pemberian lisensi pada produk varietas tanaman hasil pemuliaan tanaman di Indonesia?; (2) Bagaimana hubungan hukum antara pemberi dan penerima lisensi pada produk varietas tanaman di Indonesia?; dan (3) Bagaimana perlindungan hukum terhadap pemulia tanaman penghasil produk varietas tanaman sebagai pemberi lisensi?.

Metode penelitian yang digunakan dalam tesis ini adalah yuridis normatif dan metode analisis yang dipakai bersifat kualitatif normatif.

Pertimbangan yang mendasari penelitian terhadap hal-hal tersebut adalah belum adanya kesesuaian pengaturan mekanisme pemberian lisensi pada

produk varietas tanaman hasil pemuliaan tanaman, hubungan hukum antara pemberi dan penerima lisensi pada produk varietas tanaman, dan

perlindungan hukum bagi pemulia tanaman pada pemberian lisensi dalam undang-undang dan pelaksanaan di lapangan.

Berdasarkan analisis dan penelitian dapat disimpulkan : (1) mekanisme pemberian lisensi pada produk varietas tanaman hasil pemuliaan tanaman dilakukan secara pracontractual, contractual, dan postcontractual; (2) hubungan hukum antara pemberi dan penerima lisensi pada produk varietas tanaman lebih mempunyai kekuatan hukum bagi varietas yang telah memperoleh hak PVT; dan (3) perlindungan hukum bagi pemulia tanaman pada pemberian lisensi tidak hanya memperoleh pencantuman nama sebagai hak moral dari kekayaan intelektual yang dihasilkannya akan tetapi tetap memperoleh hak ekonomi berupa royalti dari hasil pemuliaan tanaman meskipun pemulia tidak sebagai pemegang hak PVT.
\end{abstract}

Kata kunci: Perlindungan Hukum, Lisensi, Pemulia Varietas Tanaman

1 Mahasiswa Program Studi Magister Ilmu Hukum UNDIP

2 Dosen Program Studi Magister IImu Hukum UNDIP 


\begin{abstract}
Plant breeders produce a new varieties of plants which is one part of the Intellectual Property Rights (IPR) are regulated in accordance with the laws of Indonesia, which starts from the provisions of the GATT / WTO. The results of plant breeding is regulated in statutes Number 29 year 2000 on the Plant Variety Protection. The Act gives legal protection to plant breeders and plant varieties . One of the legal protection guaranteed by the Plant Variety Protection Act is exploiting the economic value of the breeder's rights over plant varieties produced through licensing. Licenses are granted a license to use all or part of a plant variety protection rights to the person or other legal entity although plant breeder's rights holder is not a PVP or researchers in government agencies . Formulation of the problem that could be convey in this research are: (1) How does the mechanism in the product licensing of plant varieties by plant breeding in Indonesia?; (2) How does the legal relationship between licensor and licensee on products of plant varieties in Indonesia?; And (3) How does the legal protection for plant breeders of plant varieties as a licensor?. The method that used in this thesis is normative, and analytical methods that used are qualitative normative. Considerations underlying the research of these things is the lack of conformity by the regulation of licensing the products of plant breeding crop varieties, the legal relationship between the licensor and the licensee of the product license on plant varieties, and legal protection for plant breeders in the licensing laws and implementation in the field. Based on the analysis and research are: (1) the granting of a license to the products of plant breeding crop varieties performed pracontractual, contractual, and postcontractual; (2) the legal relationship between licensor and licensee on products of plant varieties has greater legal force to the varieties has acquired the rights; and (3) legal protection for plant breeders to obtain a license not only the inclusion of the name of the moral rights of the intellectual property that it generates but still gaining economic rights in the form of royalties from the breeders breeding though not as PVP rights holders.
\end{abstract}

Keywords : Legal Protection, License, Plant Variety Breeders 


\section{A. PENDAHULUAN}

\section{A.1. Latar Belakang.}

Indonesia sebagai suatu negara yang berdasarkan hukum harus melindungi hak-hak setiap warga negara serta memberikan kesamaan dihadapan hukum. Undang-Undang Dasar Negara Republik Indonesia Tahun 1945 (UUDNRI) memberikan jaminan kepada warga negara dalam memenuhi kebutuhan hidup melalui pekerjaan dalam bidang penelitian dan mendapat perlindungan atas hasil penelitian serta royalti dari penggunaan hasil penelitiannya oleh pihak lain.

${ }^{3}$ Salah satu hasil penelitian yang dapat dimanfaatkan oleh pihak lain yaitu varietas baru tanaman melalui pemuliaan tanaman. Pemuliaan tanaman merupakan suatu metode yang secara sistematik merakit keragaman genetik menjadi suatu bentuk yang bermanfaat bagi kehidupan manusia. ${ }^{4}$ Pemuliaan tanaman dilakukan dengan tujuan untuk mendapatkan varietas tanaman yang lebih baik serta dapat digunakan oleh petani dengan menguntungkan. Kegiatan pemuliaan tanaman merupakan salah satu cara guna memenuhi kebutuhan pangan nasional melalui hasil pemuliaannya. ${ }^{5}$ Kemajuan ilmu pengetahuan di bidang pertanian sangat

\footnotetext{
3 Amrin Makmur, Pengantar Pemuliaan Tanaman (Jakarta: Rineka Cipta, 1992), halaman 11.

4 Ibid, halaman 17.

5 Rachmadi Usman, Hukum Hak atas Kekayaan Intelektual "Perlindungan dan Dimensi
}

diperlukan oleh negara-negara berkembang. Indonesia sebagai negara agraris dan berkembang, serta salah satu negara di dunia yang memiliki banyak keanekaragaman hayati berupa sumber plasma nutfah dan dapat dimanfaatkan untuk merakit varietas unggul masa depan yang sangat mendukung pembangunan ekonomi sektor pertanian pada khususnya dan pembangunan nasional pada umumnya. Penelitian dan pengembangan pertanian diharapkan dapat menciptakan varietas tanaman baru untuk memenuhi kebutuhan pangan nasional setelah terlebih dahulu memperoleh inovasi berupa alih teknologi, sehingga nantinya dapat bersaing dengan produk pertanian dari negara-negara lain. Perlindungan terhadap hasil penelitian pertanian berupa varietas tanaman telah diatur di dalam Undang-Undang Nomor 29 Tahun 2000 tentang Perlindungan Varietas Tanaman (UU PVT). Perlindungan Varietas Tanaman (PVT) pada hakikatnya merupakan pelaksanaan dari berbagai kewajiban internasional yang harus dilakukan oleh Indonesia, khususnya berkaitan dengan World Trade Organization/Trade Related Aspects of Intellectual Property Rights (GATT/TRIPs), yang antara lain mewajibkan kepada tiap negara anggota mempunyai dan melaksanakan peraturan perundang-undangan di bidang Hak

Hukumnya di Indonesia (Bandung: Alumni, 2003), halaman 503 
$\begin{array}{lrr}\text { Kekayaan } & \text { Intelektual } & (\mathrm{HKI}) \\ \text { termasuk } & \text { perlindungan } & \text { varietas } \\ \text { tanaman. } & & \end{array}$

6 Kewajiban negara-negara anggota GATT/WTO untuk melindungi varietas tanaman dengan salah satu dari 3 (tiga) metode, yaitu paten, sistem sui generis yang efektif atau dengan kombinasi antara paten dan sistem sui generis. Indonesia mengacu pada sistem kombinasi PVT antara paten dan sistem sui generis yaitu bagi varietas tanaman akan berlaku undang-undang PVT sedangkan bagi proses pembentukan varietas tanaman yang bersifat mikrobiologis akan mendapat perlindungan hak paten.

Undang-Undang PVT

memberikan keadilan dan kepastian hukum bagi para pihak yang menemukan, menciptakan, dan menggunakan varietas tanaman. Pada Pasal 1 huruf 1 UU PVT dinyatakan bahwa PVT adalah perlindungan khusus yang diberikan negara, yang dalam hal ini diwakili oleh Pemerintah dan pelaksanaannya dilakukan oleh Kantor PVT, terhadap varietas tanaman yang dihasilkan oleh pemulia tanaman melalui kegiatan pemuliaan tanaman.

Pasal 1 huruf 1 ini memberikan kepastian hukum terhadap obyek dan subyek hukum atas penggunaan hasil kekayaan intelektual dalam bentuk varietas tanaman yang dihasilkan oleh

\footnotetext{
${ }^{6}$ Nina Nuraini, Perlindungan Hak Milik Intelektual Varietas Tanaman (Guna Peningkatan Daya Saing Agribisnis) (Bandung: Alfabeta, 2007), halaman 58.
}

pemulia tanaman. Jaminan hukum tersebut merupakan insentif bagi penemu varietas tanaman yang diharapkan dapat mendorong tumbuhnya investasi di bidang pemuliaan pada perspektif yang lebih luas.

Perlindungan yang diberikan oleh negara tersebut berupa pemanfaatan dari varietas tanaman yang telah memiliki hak PVT, sebagaimana disebutkan oleh Pasal 1 huruf 2 UU PVT yang menyatakan bahwa hak PVT adalah hak khusus yang diberikan negara kepada pemulia dan/atau pemegang hak PVT untuk menggunakan sendiri varietas hasil pemuliannya atau memberi persetujuan kepada orang atau badan hukum lain untuk menggunakannya selama waktu tertentu.

Tujuan perlindungan hukum terlihat dari Pasal 1 huruf 2 ini yaitu memberikan kemanfaatan, keadilan, dan kepastian hukum dalam hal penggunaan varietas tanaman hasil pemuliaan kepada pemulia dan/atau badan hukum sebagai pemegang hak PVT serta orang atau badan hukum lain dengan masa berlaku yang disepakati. Pemberian PVT juga dilaksanakan untuk mendorong dan memberi peluang kepada dunia usaha meningkatkan perannya dalam berbagai aspek pembangunan pertanian. Hal ini semakin penting mengingat perakitan varietas unggul di Indonesia saat ini masih lebih banyak dilakukan oleh lembaga penelitian pemerintah. 
${ }^{7}$ Konsep hak PVT apabila ditelusuri lebih mendalam sesuai dengan konsep HKI meliputi hak milik hasil pemikiran (intelektual), melekat pada pemiliknya, bersifat tetap dan eksklusif; dan hak yang diperoleh pihak lain atas izin dari pemilik, bersifat sementara. Pada hak PVT terdapat juga aspek hak khusus sebagaimana dimiliki oleh HKI yaitu hak ekonomi, hak moral dan fungsi sosial. Dengan adanya aspek hak khusus tersebut, pemegang hak PVT selain memperoleh hak ekonomi berupa royalti, hak moral yang melindungi reputasi pencipta dan inventor juga harus mempunyai fungsi sosial yang dapat digunakan untuk kepentingan umum.

Pemberian hak PVT oleh negara kepada penemu varietas tanaman diperlukan karena pemulia sebagai orang yang dengan sengaja melakukan perakitan varietas baru tanaman dengan menggunakan metode baku pemuliaan, yaitu kegiatan yang memerlukan waktu lama dengan dana besar secara berkesinambungan. Akan tetapi setelah varietas baru tersebut dilepas ke masyarakat/pasar, pemulia sebagai inventor haknya terlanggar karena mudahnya memperbanyak varietas tersebut tanpa izin dan pemulia tidak lagi dapat memperoleh manfaat secara ekonomi dari invensinya. Tanpa adanya perlindungan kepada pemulia maka perakitan varietas akan sangat

7 Abdulkadir Muhammad, Kajian Hukum Ekonomi Hak Kekayaan Intelektual (Bandung: Citra Aditya Bakti, 2001), halaman 1. terpojok dan kurang diminati.

8 Varietas tanaman yang mempunyai manfaat ekonomi dan dapat dikomersilkan harus memenuhi beberapa persyataran sebagai berikut: (1) mempunyai kemampuan berproduksi yang tinggi; (2) mempunyai kualitas hasil panen yang baik; dan (3) mempunyai kepastian hasil panen. Varietas tanaman dalam pemanfaatannya perlu adanya inovasiinovasi baru guna menciptakan varietas unggul yang memiliki nilai ekonomi. Motif untuk memperoleh keuntungan adalah motif utama yang mendorong dilakukannya eksploitasi dan komersialisasi HKI.

Hak Kekayaan Intelektual diberikan kepada pemulia, atau siapapun yang menyatakan telah menemukan atau mengembangkan varietas baru tanaman. Varietas tanaman yang dilindungi oleh UU PVT pada Pasal 1 angka 3 adalah sekelompok tanaman dari suatu jenis atau spesies yang ditandai oleh bentuk tanaman, pertumbuhan tanaman, daun, bunga, buah, biji, dan ekspresi karakteristik genotipe atau kombinasi genotipe yang dapat membedakan dari jenis atau spesies yang sama oleh sekurang-kurangnya satu sifat yang menentukan dan apabila diperbanyak tidak mengalami perubahan.

9 Hukum menjamin

\footnotetext{
${ }^{8}$ W. Mangoendidjojo, Dasar-Dasar Pemuliaan Tanaman (Yogyakarta: Kanisius, 2007), halaman 2.

9 Muhammad Djumhana dan R. Djubaedillah, Hak Milik Intelektual, Sejarah. Teori dan
} 
kepemilikan dan menjamin setiap manusia untuk penguasaan dan menikmati secara eksklusif atas benda atau ciptaannya yang dihasilkannya dengan bantuan negara, dengan demikian gambaran tersebut menunjukkan bahwa perlindungan hukum adalah untuk kepentingan si pemilik (pemulia), baik pribadi maupun kelompok yang merupakan subyek hukum.

Hak PVT dapat dimanfaatkan oleh orang lain atau badan hukum melalui suatu perjanjian lisensi. Lisensi varietas tanaman menurut UU PVT pada Pasal 1 angka 13 adalah izin yang diberikan oleh pemegang hak PVT kepada orang atau badan hukum lain untuk menggunakan seluruh atau sebagian hak PVT.

Pemegang hak PVT dalam hal varietas tanamannya memiliki manfaat komersial dapat memberikan izin kepada orang atau badan hukum lain untuk menggunakannya melalui perjanjian lisensi dengan tujuan memperoleh keuntungan berupa royalti dan keuntungan hasil penjualan varietas tanaman bagi penerima hak PVT.

Pemilik hak PVT berhak memberikan lisensi kepada orang atau badan hukum lain berdasarkan perjanjian lisensi sesuai dengan Pasal 42 ayat (1) UU PVT. Pengecualian terhap pemberian lisensi hak PVT yaitu apabila diperjanjikan lain, maka pemegang hak PVT tetap boleh melaksanakan sendiri atau

Praktiknya di Indonesia (Bandung: Citra Aditya Bakti, 2003), halaman 25. memberi lisensi kepada pihak ketiga lainnya.

Undang-Undang PVT telah mengamanatkan terbentuknya Peraturan Pemerintah mengenai perjanjian lisensi sebagaimana tercantum pada Pasal 43 ayat (3), yang menyatakan bahwa ketentuan mengenai perjanjian lisensi diatur lebih lanjut dengan Peraturan Pemerintah. Pada penjelasan pasal ini menyatakan bahwa hal-hal yang diatur dalam Peraturan Pemerintah mengenai perjanjian lisensi meliputi hak dan kewajiban pemberi dan penerima lisensi termasuk bagianbagian dari pelaksanaan hak PVT yang dilisensikan, jangka waktu serta bentuk perjanjian lisensi tersebut.

Peraturan pemerintah yang mengatur tentang perjanjian lisensi sesuai amanat dari UU PVT diatur dalam Peraturan Pemerintah Nomor 14 Tahun 2004 tentang Syarat Dan Tata Cara Pengalihan Perlindungan Varietas Tanaman Dan Penggunaan Varietas Yang Dilindungi (PP Nomor 14 Tahun 2004) pada Pasal 20-Pasal 28, serta tetap mengacu pada syarat-syarat lahirnya lisensi sebagai suatu perjanjian terpenuhi secara sah. Pelaksanaan perjanjian lisensi secara yuridis tetap berpedoman kepada Kitab Undang-Undang Hukum Perdata (KUHPerdata), yaitu Pasal 1313, Pasal 1320, Pasal 1338 KUHPerdata, dan Pasal 1365 KUHPerdata.

${ }^{10}$ Bentuk-bentuk lisensi HKI

\footnotetext{
10 Etty S. Suhardo, Hak Kekayaan Intelektual dan Lisensi HKI (Semarang: Magister Ilmu
} 
tidak diatur dalam Undang-Undang HKI. Undang-Undang HKI baik Paten, Merek, Cipta hanya mengatur lisensi sukarela dan lisensi wajib, bukan jenis lisensi seperti lisensi eksklusif dan non eksklusif. Sebagai contoh dalam prakteknya terkait lisensi Paten ada 3 (tiga) macam lisensi yaitu: ${ }^{11}$ (1) lisensi eksklusif; (2) lisensi tunggal; dan (3) lisensi non-eksklusif. Meskipun Undang-Undang tidak mengatur tentang jenis lisensi sukarela atau bentuk lisensi lain namun Hukum HKI telah mengembangkan bentuk-bentuk lisensi menjadi (1) Lisensi Eksklusif; (2) Lisensi Non Eksklusif; dan Lisensi Silang. Berkaitan dengan PVT terdapat 2 (dua) jenis lisensi yaitu lisensi sukarela yang terdiri dari lisensi eksklusif \& lisensi non eksklusif, dan lisensi wajib.

Pemberian lisensi varietas tanaman yang dilakukan oleh para pihak dengan tujuan komersialisasi nantinya akan memberikan hubungan hukum, perlindungan hukum, dan akibat hukum. Hubungan hukum, perlindungan hukum, dan akibat hukum yang terjadi merupakan sebuah konsekuensi dari timbulnya perjanjian dalam memanfaat varietas tanaman unggul guna memperoleh keuntungan ekonomi bagi para pihak yang melakukan perjanjian terutama pemulia varietas tanaman secara

Hukum Universitas Dipenogoro, 2012), halaman 79.

11 Endang Purwaningsih, Hak Kekayaan Intelektual (HKI) dan Lisensi (Bandung: Mandar Maju, 2012), halaman 117. perseorangan maupun badan hukum.

\section{A.2. Permasalahan.}

1. Bagaimana mekanisme pemberian lisensi pada produk varietas tanaman hasil pemuliaan tanaman di Indonesia?;

2. Bagaimana hubungan hukum antara pemberi dan penerima lisensi pada produk varietas tanaman di Indonesia?;

3. Bagaimana perlindungan hukum terhadap pemulia tanaman penghasil produk varietas tanaman sebagai pemberi lisensi?.

\section{A.3. Tujuan dan Kontribusi Penelitian. \\ Tujuan Penelitian:}

1. Untuk mengkaji dan menganalisis mekanisme pemberian lisensi produk varietas tanaman hasil pemuliaan tanaman di Indonesia;

2. Untuk mengkaji dan menganalisis hubungan hukum antara pemberi dan penerima lisensi produk varietas tanaman di Indonesia;

3. Untuk mengkaji dan menganalisis perlindungan hukum terhadap pemulia tanaman penghasil produk varietas tanaman sebagai pemberi lisensi.

\section{Kontribusi Penelitian:}

1. Kontribusi Teoritis. 
Hasil penelitian ini diharapkan dapat digunakan sebagai sumbangsih terhadap dunia pendidikan dan hukum, juga sebagai kajian terhadap pengembangan ilmu pengetahuan dan hukum, khususnya hukum HKI.

2. Kontribusi Praktis.

Diharapkan menyumbangkan pemikiran kepada para sarjana hukum pada umumnya dan para sarjana hukum yang menekuni masalah HKI yang terkait dengan pemberian lisensi hak PVT pada khususnya, yaitu bagi mereka yang bekerja sebagai konsultan HKI, konsultan hukum di perusahaan swasta maupun peneliti dan bagian hukum pada lembaga pemerintahan, seperti Kementerian Hukum dan Hak Asasi Manusia (HAM), Kementerian Pertanian, dan lain-lain.

\section{A.4. Tinjauan Pustaka.}

Hak Kekayaan Intelektual adalah hak kebendaan yang dimiliki seseorang yang timbul dari kemampuan kreatifitas intelektual manusia yang kemudian dikreasikan dalam berbagai bentuk karya-karya tertentu dibidang ilmu pengetahuan dan teknologi, seni dan sastra, serta memiliki nilai ekonomi yang dapat dimanfaatkan atau dipergunakan oleh pemiliknya ataupun pemegang haknya. Sifat HKI adalah merupakan sifat-sifat yang ditemukan dalam
HKI. HKI merupakan perlindungan hak yang diberikan oleh negara dan bersifat eksklusif, dapat dialihkan kepada pihak lain, serta memiliki nilai ekonomis, dan tidak dapat disita.

Prinsip-prinsip HKI bersifat universal yang merupakan nilai-nilai yang terkandung dalam pengaturan HKI serta peraturan perundangundangan yang akan diterapkan dan dicapai oleh undang-undang HKI. Beberapa prinsip universal yang terkandung dalam HKI, antara lain sebagai berikut: ${ }^{12}$ 1) perlindungan hukum karya intelektual; 2) keseimbangan hak dan kewajiban; 3) keadilan; 4) perlindungan ekonomi dan moral; 5) teritorialitas; 6) kemanfaatan; 7) moralitas; dan 8) alih teknologi dan penyebaran teknologi. HKI pada dasarnya merupakan hak milik yang diatur dalam ${ }^{13}$ KUHPerdata pada Pasal 570, maka setiap orang yang mempunyai hak milik atas sesuatu hal/benda mempunyai hak untuk menikmati manfaat yang dapat diambil dari benda tersebut selama tidak bertentangan dengan undang-undang dan peraturan yang berlaku. Pemilik mempunyai kekuasaan terhadap benda tersebut, sehingga ia mempunyai hak untuk melakukan setiap tindakan terhadap

12 Candra Irawan, Politik Hukum Hak Kekayaan Intelektual Indonesia (Kritik Terhadap WTO/TRIPs Agreement dan Upaya Membangun Hukum Kekayaan Intelektual Demi Kepentingan Nasional) (Bandung: Mandar Maju, 2011), halaman 53-55.

13 Muhammad Djumhana \& Djubaedillah, Op.Cit., halaman 31 
benda tersebut, misalnya untuk mengalihkan hak milik itu kepada orang lain atau memusnahkannya. Setiap hak yang kita miliki tidak boleh bertentangan dan merugikan hak yang dimiliki oleh orang lain, termasuk didalamnya HKI. Berdasarkan pada hal-hal tersebut diatas maka HKI memiliki banyak sekali manfaat yang dapat diambil karena mempunyai nilai ekonomi yang tinggi bagi pencipta, penemu, dan pemegang hak.

14 Pengalihan HKI dapat dilakukan melalui pewarisan, wasiat, hibah, perjanjian, atau sebab-sebab lain yang diperkenankan oleh peraturan undang-undang (putusan pengadilan) sebagaimana diatur pada Pasal 40 UU PVT. Pengalihan HKI tidak menghilangkan hak moral dari pencipta atau penemu. Pengalihan dengan perjanjian biasanya dapat berupa lisensi, joint venture, kontrak penelitian, dan sebagainya. Hasil penelitian berupa varietas tanaman yang diklasifikasikan sebagai HKI menurut

Koerniatmanto

Soetoprawiro merupakan bagian dari hukum pertanian apabila di lihat dari sudut hukum ekonomi, hukum pertanian mengatur tentang masalah agribisnis dan agroindustri. ${ }^{15}$ Keterkaitan dengan agribisnis dan agroindustri maka Hak Kekayaan Intelektual menjadi perhatian dalam kajian Hukum Pertanian. ${ }^{16}$ Oleh

\footnotetext{
14 Ibid, halaman 35.

15 Koerniatmanto Soetoprawiro, Pengantar Hukum Pertanian (Jakarta: Gapperindo, 2013), halaman 77 .

16 Ibid, halaman 51
}

karenanya, obyek pengaturan dan pengayoman hukum pertanian adalah urusan pertanian berserta produk-produknya, baik pangan maupun non pangan dengan segenap aspeknya. Pemberian PVT kepada pemulia terhadap varietas tanaman yang dihasilkan melalui kegiatan pemuliaan tanaman harus memenuhi persyaratan yang telah ditentukan oleh undang-undang. Varietas tanaman yang diberikan perlindungan harus memenuhi unsur-unsur sebagaimana diatur pada Pasal 2 UU PVT.

Ketentuan mengenai syarat dan tata cara pengalihan hak PVT diatur lebih jelas pada PP Nomor 14 Tahun 2004 pada Pasal 2-Pasal 19. Selain dicatatkan pada Kantor PVT, pengalihan hak PVT juga dicatat dalam Daftar Umum PVT dengan membayar biaya yang besarnya ditetapkan oleh Menteri Pertanian berdasarkan Keputusan Menteri Pertanian Nomor 443/Kpts/KU.330/7/2004 tentang Biaya Pengelolaan Hak Perlindungan Varietas Tanaman.

${ }^{17}$ Varietas tanaman dihasilkan melalui pemuliaan tanaman yaitu melalui rangkaian kegiatan penelitian dan pengujian atau kegiatan penemuan dan pengembangan suatu varietas, sesuai dengan metode baku untuk menghasilkan varietas baru dan mempertahankan kemurnian benih varietas yang dihasilkan.

17 Nina Nuraini, Op.Cit., halaman 24. 
${ }^{18}$ Pengertian pemuliaan tanaman ini sama dengan yang tercantum pada Pasal 1 ayat (4) UU PVT. Pemuliaan dapat dilakukan di dalam negeri dan dapat pula diperoleh melalui introduksi (pemasukan) varietas dari luar negeri. Pemuliaan tanaman dilaksanakan oleh pemulia tanaman sebagaimana diatur pada Pasal 1 huruf 5 UU PVT.

Pemuliaan tanaman yang dilakukan tidak hanya diarahkan untuk menghasilkan varietas tanaman unggul baru, melainkan juga untuk mempertahankan kemurnian varietas yang sudah ada. Kegiatan pemuliaan tanaman tidak hanya dilakukan dengan menggunakan teknik konvensional akan tetapi juga telah dilakukan melalui pemuliaan modern berupa teknik rekayasa genetik ${ }^{19}$, berbagai keunggulan yang diharapkan dari suatu varietas tanaman memiliki peluang lebih besar untuk dipenuhi. Hal ini disebabkan dalam proses pembentukannya, berbagai gen yang memiliki berbagai keunggulan dapat digabungkan menjadi satu. Pemulia tanaman sebelum melakukan pemuliaan tanaman perlu mengetahui akan tujuan dan masalah serta harapan produsen dan konsumen dari hasil pemuliaan ${ }^{20}$. Tujuan pemuliaan tanaman secara lebih luas adalah memperoleh atau mengembangkan varietas agar lebih efisien dalam penggunaan unsur hara

\footnotetext{
18 Ibid.

19 Ibid.
}

dan tahan terhadap cekaman biotik dan abiotik sehingga memberi hasil tertinggi per satuan luas dan menguntungkan bagi penanam serta pemakai ${ }^{21}$. Tahapan kegiatan pemulian tanaman dapat dilakukan melalui: 1) Koleksi Plasma Nutfah, 2) Karakterisasi, 3) Seleksi, 4) Perluasan Keragaman Genetik (Hibridasi, Mutasi, Fusi Protoplas, dan Rekayasa Genetik), 5) Seleksi setelah Perluasan Keragaman Genetik, 6) Evaluasi dan Pengujian, dan 7) Pelepasan Varietas dan Perbanyakan. Dalam perjanjian lisensi terdapat para pihak yang berkepentingan, antara lain: 1 . pihak langsung yaitu (a) pemilik atau pemberi HKI (licensor) yang terdiri dari pemilik HKI, pemilik bersama (co-owner) HKI, dan penerima lisensi dalam hubungan dengan sub lisensi (b) penerima lisensi (licensee) yang terdiri dari individu atau badan hukum; 2. pihak tidak langsung yaitu lembaga yang mempunyai tugas, pokok dan fungsi dalam proses atau pelaksanaan perjanjian lisensi seperti Pengadilan atau Kantor PVT.

Pengaturan mengenai lisensi dalam UU PVT diatur pada Pasal 42Pasal 55 dan terbagi dalam 2 (dua) macam yaitu lisensi biasa dan lisensi wajib. Lisensi biasa yang dimaksud merupakan lisensi yang terjadi karena kesepakatan antara pemberi lisensi dan penerima lisensi, sedangkan lisensi wajib merupakan

\footnotetext{
20 Muhammad Syukur, Sriani Sujiprihati dan Rahmi Yunianti, Teknik Pemuliaan Tanaman (Jakarta: Penebar Swadaya, 2012), halaman 6. ${ }^{21}$ Ibid, halaman 8
} 
lisensi yang terjadi karena keputusan pemerintah seperti pengajuan permohonan melalui pengadilan. Pengaturan mengenai lisensi varietas tanaman pada PP Nomor 14 Tahun 2004 tercantum pada Pasal 20-Pasal 32 yang mengatur mengenai lisensi biasa dan lisensi wajib.

Perjanjian lisensi yang akan dilakukan oleh para pihak hanya dapat dilakukan bagi varietas tanaman yang telah memperoleh hak PVT guna memberikan perlindungan hukum kepada pihak yang memegang hak PVT dan pemulia tanaman.

\section{A.5. Metode Penelitian.}

Metode pendekatan yang digunakan dalam penelitian ini adalah metode pendekatan yuridis normatif untuk mengungkapkan berbagai perangkat hukum yang dapat dilihat dan digunakan dalam UU PVT. Demikian juga dengan tujuannya yaitu untuk menemukan asas-asas hukum yang dapat menjadi patokan dalam menentukan pelaksanaan dan filosofi dari UU PVT dikaitkan dengan perlindungan hukum pada pemberian lisensi bagi pemulia varietas tanaman berdasarkan UU PVT dan undang-undang terkait lainnya.

Penelitian ini bersifat deskriptif analitis karena secara spesifik penelitian ini bertujuan memberikan gambaran mengenai berbagai sudut pandang dari UU PVT, UU Nomor 18 Tahun 2002, UU Nomor 14 Tahun 2004, dan PP Nomor 20 Tahun 2005, dilihat dari aspek hukumnya, karakteristiknya, dan perlindungan hukum pada pemberian lisensi bagi pemulia varietas tanaman.

\section{B. HASIL PENELITIAN DAN PEMBAHASAN.}

\section{B.1. Mekanisme pemberian lisensi} pada produk varietas tanaman hasil pemuliaan tanaman di Indonesia.

Pemanfaatan nilai ekonomi dari suatu varietas hasil pemuliaan tanaman oleh orang dan badan hukum menurut UU PVT dilakukan melalui lisensi. Lisensi yang diberikan adalah bagi varietas tanaman yang telah memiliki hak PVT. Mekanisme dalam melaksanakan perjanjian lisensi yang dilakukan oleh pemberi dan penerima lisensi berdasarkan kepada tahapan membuat perjanjian menurut teori baru ${ }^{22}$, yaitu: 1. Tahap pracontractual, yaitu adanya penawaran dan penerimaan; 2. Tahap contractual, yaitu adanya persesuaian pernyataan kehendak antara para pihak; 3. Tahap post contractual, yaitu pelaksanaan perjanjian. Perencanaan kontrak atau perjanjian lisensi yang disampaikan oleh Etty Susilowati apabila dikaitkan dengan mekanisme yang dikemukakan oleh teori baru, maka perencanaan kontrak tersebut termasuk ke dalam tahap pracontractual. Perencanaan kontrak lisensi tersebut sebaiknya dilakukan

\footnotetext{
22 Salim HS., Pengantar Hukum Perdata Tertulis (BW) (Jakarta: Sinar Grafika, 2009), halaman 161.
} 
oleh para pihak guna menyesuaikan pernyataan kehendak keduanya sehingga terjadi kesepakatan antara kedua belah pihak.

Mekanisme pemberian lisensi produk varietas tanaman dapat diuraikan sebagai berikut:

\section{Tahap Pracontractual :}

Pada tahap pracontractual terjadi penawaran dan penerimaan dari para pihak yang akan melaksanakan perjanjian lisensi varietas tanaman. Prinsip utama dalam melakukan lisensi terhadap varietas tanaman adalah varietas tanaman yang akan dilisensikan telah memperoleh hak PVT, sehingga para pihak yaitu pemberi dan penerima lisensi dapat terlindungi haknya dalam pemanfaatan varietas tanaman.

2. Tahap Contractual:

Pada tahap contractual terjadi penyesuaian kehendak dari para pihak melalui ketentuan-ketentuan yang diatur dalam perjanjian lisensi. Pada Pasal 20 PP Nomor 14 Tahun 2004 diatur tentang ketentuan mengenai Isi Perjanjian Lisensi yang akan diatur oleh para pihak. Pada Bagian kedua tentang lisensi mengatur mengenai hak dan kewajiban pemberi dan penerima lisensi yang diatur pada Pasal 21-Pasal 24 guna memberikan keseimbangan bagi para pihak. Salah satu kewajiban yang harus dilakukan oleh para pihak dalam perjanjian lisensi yaitu bahwa perjanjian lisensi varietas tanaman harus dicatatkan pada Kantor PVT. Pihak penerima lisensi pada Pasal 24 huruf $b$ adalah pihak yang mencatatkan perjanjian lisensi tersebut. Meskipun dalam ketentuan perundang-undangan tidak mengatur mengenai pihak yang dikenakan biaya pencatatan perjanjian lisensi varietas tanaman, biasanya penerima lisensi yang akan bertanggung jawab terhadap biaya pencatatan tersebut.

Penerima lisensi sebagai pihak yang akan memanfaatkan hasil pemuliaan tanaman merupakan pihak yang akan mencatatkan perjanjian lisensi sesuai dengan Bagian Ketiga tentang lisensi mengatur mengenai syarat dan tata cara permohonan pencatatan perjanjian lisensi yang diatur pada Pasal 25.

\section{Tahap Postcontractual:}

Pada tahap postcontractual ini, pemberi dan penerima lisensi setelah tahap pracontractual dan tahap contractual melakukan pelaksanaan perjanjian sesuai isi dalam perjanjian lisensi varietas tanaman. Para pihak berdasarkan isi perjanjian melakukan hak dan kewajibannya masing-masing serta dapat melakukan perbaikanperbaikan dari perkembangan pelaksanaan perjanjian lisensi varietas tanaman.

Pada tahap ini dimungkinkan terjadinya kendala-kendala dan masalah-masalah yang dihadapi dalam pelaksanaan isi perjanjian, seperti halnya hasil dari perbanyakan varietas tanaman yang tidak sesuai dengan yang 
diperjanjikan ataupun penyediaan varietas tanaman yang tidak sesuai dengan kualitas yang diperjanjikan sehingga dapat terjadi peninjauan kembali terhadap perjanjian yang telah disepakati. Kegiatan menghasilkan varietas tanaman yang memiliki nilai ekonomi yang tinggi haruslah dilakukan dengan penelitian yang memerlukan teknologi dan modal besar. Pemilik teknologi dan modal besar yang dapat menghasilkan varietas tanaman unggul hanyalah pemerintah melalui Badan Penelitian dan Pengembangan Pertanian, Kementerian Pertanian (Balitbangtan, Kementan) serta badan usaha yang bergerak dalam bidang perbenihan.

Mekanisme pemberian lisensi pada varietas tanaman yang memerlukan proses alih teknologi invensi berbasis HKI pada Balitbangtan, Kementan diatur berdasarkan Standar Operasional Prosedur (SOP) tentang Proses Alih Teknologi Invensi Berbasis HKI Nomor 36/OT.225/I.1.1/01/2011 tertanggal 15 Januari 2010 serta telah dilakukan revisi pada tanggal 7 Januari 2011 dan mulai berlaku pada 8 Februari 2011. Pelaksanaan SOP tentang Proses Alih Teknologi Invensi Berbasis HKI memiliki keterkaitan dengan SOP lain yaitu SOP Kerjasama dan Humas, Balitbangtan, SOP HKI (Paten, Cipta, Merek, PVT), dan SOP Lisensi.

Pelaksanaan pemberian lisensi bagi varietas tanaman hasil pemuliaan tanaman oleh pemulia Balitbangtan, Kementan yang berlokasi pada Unit Kerja/Unit Pelaksana Teknis (UK/UPT) sesuai dengan SOP Nomor 36/OT.225/I.1.1/01/2011 haruslah telah memperoleh surat daftar/sertifikat sebagai bentuk perlindungan hukum/perlindungan sementara atas invensi yang dihasilkan.

Permasalahan yang timbul adalah apabila pelaksanaan pemberian lisensi dilakukan sebelum adanya sertifikat hak PVT atau tanda daftar perlindungan sementara yang diterbitkan oleh Kantor PVT. Akibat hukum yang ditimbulkan oleh perjanjian lisensi tersebut bagi para pihak yaitu pemberi dan penerima lisensi serta pemulia tanaman sebagai pihak yang melakukan pemuliaan tanaman.

Varietas tanaman yang telah dilakukan perjanjian lisensi pada Balitbangtan, Kementan yang belum memperoleh sertifikat hak PVT ataupun tanda daftar perlindungan sementara atas varietas tanaman berdasarkan Data Kerjasama Lisensi Invensi Balitbangtan dengan Dunia Usaha dari 2007 sampai September 2012 sebanyak 8 (delapan) invensi varietas tanaman.

Mekanisme pemberian lisensi pada 8 (delapan) varietas tanaman tersebut dilakukan tanpa melalui pendaftaran terlebih dahulu untuk memperoleh sertifikat hak PVT 


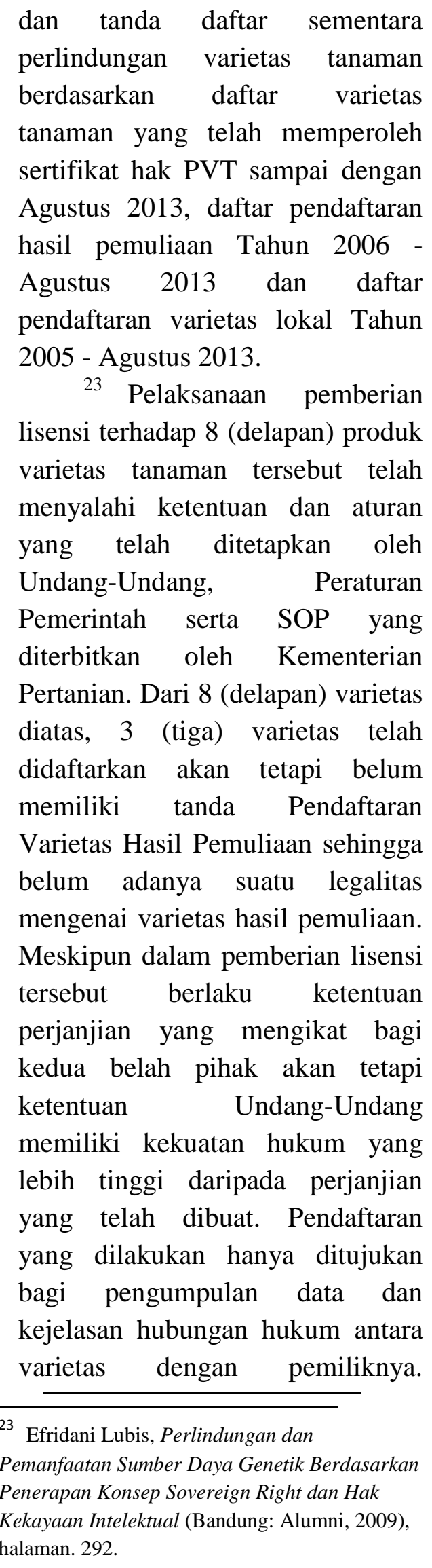

Pendaftaran varietas sangat dianjurkan, namun pendaftaran tidak memberikan perlindungan ekonomi bagi pemilik, hanya saja bisa dijadikan prior art (state of the art) dari varietas sejenis. Untuk perlindungan secara ekonomi maka mekanisme yang digunakan adalah Perlindungan Varietas tanaman (PVT).

\section{B.2. Hubungan hukum antara pemberi dan penerima lisensi pada produk varietas tanaman di} Indonesia. Pengakuan terhadap hasil
pemuliaan yang dilakukan oleh
pemulia tanaman dan harus tetap
diakui memiliki hubungan hukum dengan varietas tanamannya merupakan salah satu ketentuan yang diatur dalam UU PVT. Ketentuan tersebut harus dipatuhi oleh semua pihak termasuk lembaga penelitian dan pengembangan pemerintah. Meskipun hasil pemuliaan tersebut telah dialihkan kepada lembaga penelitian dan pengembangan tersebut, akan tetapi hak pemulia sebagai inventor tetap harus diakui termasuk dalam perjanjian pemberian lisensi varietas tanaman. Salah satu contoh yang dapat penulis sampaikan yaitu pada Balitbangtan, Kementan pengalihan/pemindahan hak PVT dari inventor kepada UK/UPT dilakukan sejak akan dilaksanakannya pemuliaan tanaman. Walaupun pengalihan telah dilaksanakan melalui perjanjian tertulis, akan tetapi pemulia tanaman harus tetap dilindungi haknya dan 
tetap mempunyai hubungan hukum dengan hasil pemuliaannya serta harus memperoleh penghargaan atas kekayaan intelektual yang dihasilkannya. Perjanjian pengalihan tersebut meskipun tidak terikat pada suatu bentuk tertentu, namun dalam pembuatannya harus memperhatikan peraturan-peraturan nasional dan ketentuan-ketentuan internasional.

Hubungan hukum antara pemberi dan penerima lisensi dalam perjanjian lisensi menghasilkan hak dan kewajiban, selain itu hakikat hubungan hukum lain yang terjadi adalah dalam hal penyelesaian sengketa. Pada Balitbangtan, Kementan dalam perjanjian lisensi varietas tanaman perihal klausul penyelesaian sengketa yang tidak mencantumkan mengenai penyelesaian sengketa melalui pengadilan, sebagaimana tercantum dalam perjanjian lisensi yang lain seperti pada lisensi paten. Penyelesaian sengketa yang dicantumkan dalam perjanjian lisensi yaitu melalui cara arbitrase yang juga memerlukan bantuan pengadilan sebagai pihak terakhir apabila tidak dapat diselesaikan melalui arbitrer yang disediakan oleh pemberi dan penerima lisensi. Penyelesaian melalui arbitrase merupakan cara yang digunakan para pihak untuk menghindari terjadinya penyelesaian melalui pengadilan, akan tetapi kadangkala penyelesaian dengan menggunakan arbiter mengalami kebuntuan atau tidak menyelesaikan permasalahan yang ada. Oleh karenanya untuk menyelesaikan permasalahan diperlukan pencantuman klausul penyelesaian sengketa melalui pengadilan sebagai jalan terakhir. Perjanjian lisensi PVT yang dibuat oleh Kementerian Pertanian merupakan perjanjian baku yang harus dipatuhi oleh UK/UPT yang akan melaksanakan perjanjian lisensi PVT dengan pihak lain (badan usaha).

Pendapat lain dikemukakan oleh Dwi Pudiastuti, Kepala Bagian Perundangan I, Biro Hukum dan Humas, Kementerian Pertanian menyatakan bahwa tidak dicantumkannya klausul penyelesaian sengketa melalui pengadilan dikarenakan karakteristik dari pemulia tanaman sendiri yang telah melakukan penelitian dalam menghasilkan varietas baru tanaman yang memerlukan waktu, tenaga dan biaya yang banyak sehingga diantara para pemulia tanaman telah adanya suatu kebiasaan yaitu kepercayaan diantara para pemulia tanaman. Penyelesaian sengketa yang dilakukan oleh Balitbangtan, Kementan melalui penyelesaian sengketa diluar pengadilan (arbitrase).

Meskipun pemulia tanaman mempunyai karakteristik tersendiri, akan tetapi penggunaan pencantuman klausul penyelesaian sengketa melalui pengadilan merupakan salah satu bagian dari perlindungan hukum yang diberikan kepada pemberi dan penerima lisensi apabila dikemudian hari terjadi pelanggaran dalam pelaksanaan 
perjanjian yang telah dibuat oleh para pihak. Oleh karenanya dalam setiap perjanjian lisensi akan lebih baik tetap mencantumkan klausul penyelesaian sengketa di pengadilan untuk lebih menimbulkan kepastian hukum dan perlindungan hukum bagi kedua belah pihak.

\section{B.3. Perlindungan hukum terhadap pemulia tanaman penghasil produk varietas tanaman sebagai pemberi lisensi.}

${ }^{24}$ HKI sebagai satu sistem perlindungan hukum mempunyai dua jenis perlindungan sebagaimana diungkapkan oleh Philipus M. Hadjon yaitu: Sistem pendaftaran yang cenderung kepada perlindungan hukum secara preventif dan sistem pidana untuk perlindungan secara represif, mengingat pidana pada asasnya adalah satu tindakan terakhir untuk menegakkan hukum. Untuk mendapatkan perlindungan HKI adanya pendaftaran saja tidak cukup, sehingga memerlukan kelengkapan syarat-syarat formil dan materiil dalam suatu pendaftaran yang akan menentukan pada diterima atau tidaknya suatu permohonan hak. Dengan terpenuhinya syarat formil dan materiil serta dilakukan pendaftaran maka akan melahirkan hak eksklusif.

Keuntungan mengenai

24 Budi Agus Riswandi dan Shabhi Mahmashani, Dinamika Hak Kekayaan Intelektual Dalam Masyarakat Kreatif (Yogyakarta: Total Media, 2009), halaman 12. pengaturan perlindungan varietas tanaman di Indonesia yang menggunakan kedua Undang-Undang tersebut dikemukakan juga oleh Joshua V. Funder dalam buku Hak Kekayaan Intelektual Suatu Pengantar yang intinya menyatakan bahwa Perlindungan ganda dari kedua Undang-Undang yang saling melengkapi memberikan manfaat besar kepada para pemulia tanaman yang selanjutnya dapat digunakan sebagai reward atas keberhasilan mereka memajukan pertanian di Indonesia ${ }^{25}$. Perlindungan ganda terhadap varietas tanaman di Indonesia merupakan tindakan yang diperbolehkan baik menurut hukum positif nasional maupun menurut hukum internasional ${ }^{26}$. Hal ini disebabkan substansi yang diatur oleh kedua Undang-Undang tersebut sangat berbeda, sehingga saling melengkapi satu sama lain.

Dengan menyediakan perlindungan ganda melalui UU Paten dan UU PVT Indonesia, kepentingan para pemulia tanaman terhadap varietas yang ditemukannya dapat dilindungi secara maksimal. Upaya penelitian atau pelepasan varietas-varietas unggul baru dilakukan oleh para pemulia yang bekerja di kelembagaan pemerintah $^{27}$, baik di balai-balai

\footnotetext{
25 Tim Lindsey, et al, Hak Kekayaan Intelektual "Suatu Pengantar" (Bandung: Alumni, 2011), halaman 396-397

${ }^{26}$ Ibid, halaman 399

27 Sabartua Tampublon, Politik Hukum Iptek di Indonesia (Yogyakarta: Kepel Press, 2013), halaman 133.
} 
penelitian maupun di perguruan tinggi, sedangkan lembaga penelitian dan pengembangan swasta di Indonesia belum berkembang dengan baik. Lembaga penelitian dan pengembangan swasta dapat berdiri sendiri atau merupakan divisi penelitian dan pengembangan dari suatu badan usaha. Perlindungan varietas tanaman dimaksudkan bahwa pemilik varietas yang dilindungi dapat memberikan hak kepada perusahaan benih tertentu untuk memperbanyak, memproduksi, dan memperdagangkan benih varietas yang bersangkutan dengan mutu yang terjamin dan harga yang layak. Pada saat ini yang terjadi adalah petani semakin sulit memperoleh benih yang berkualitas karena umumnya diproduksi oleh perusahaan multinasional yang profit oriented sehingga harganya menjadi sangat mahal. Lembaga penelitian dan perguruan tinggi sebagai penyedia public goods perlu didukung penuh sehingga mampu menghasilkan teknologi dan inovasi alternatif yang bisa diakses secara murah oleh publik utamanya petani-petani kecil di pedesaan ${ }^{28}$.

Bagi Indonesia, adanya bentuk hak pemulia yang tercakup dalam UU PVT merupakan satu hal penting karena pemulia Indonesia hanya menganggap penting hasil akhir berupa "produk" varietas tanaman yang tidak terakomodasi

28 Subejo, Bunga Rampai Pembangunan Pertanian dan Pedesaan (Jakarta: Universitas Indonesia, 2013), halaman 16. melalui hak paten ${ }^{29}$. Apabila diperbandingkan dengan Australia dan Belanda yang mengatur hak pemulia dalam hukum nasionalnya masing-masing dengan tujuan dan harapan yang sama, yaitu mendukung upaya pengembangan invensi varietas tanaman yang tidak dapat dilindungi dengan hak paten. Saat ini alih teknologi atas invensi yang berpotensi komersial dan sudah mendapatkan perlindungan varietas tanaman ${ }^{30}$, dilaksanakan melalui kerjasama lisensi yang menghasilkan jasa alih teknologi berupa royalti. Hasil kerjasama lisensi berupa royalti tanpa terkecuali harus disetorkan ke Kas Negara dalam bentuk Pendapatan Negara Bukan Pajak (PNBP) ${ }^{31}$. Berkaitan dengan royalti yang diterima dari lisensi yang dilakukan oleh UK/UPT terutama varietas tanaman seharusnya pemulia tanaman yang melakukan pemuliaan tanaman berdasarkan UU PVT pada Pasal 8 harus mendapatkan imbalan yang layak dengan memperhatikan manfaat ekonomi yang dapat diperoleh dari varietas tersebut. Pendapat yang sama dikemukakan juga oleh Adrian Sutedi mengenai penyebab utama masih rendahnya tingkat pengajuan paten oleh peneliti Indonesia, yang menurut penulis

\footnotetext{
29 Andriana Krisnawati \& Gazalba Saleh, Perlindungan Hukum Varietas Baru Tanaman Dalam Perspektif Hak Paten dan Hak Pemulia (Jakarta: RajaGrafindo Persada, 2004), halaman 106-107.

${ }^{30}$ http://bpatp.litbang.deptan.go.id/index

31 Adrian Sutedi, Hak Atas Kekayaan Intelektual (Jakarta: Sinar Grafika, 2013), halaman 7.
} 
juga terjadi bagi pengajuan perlindungan varietas tanaman yaitu salah satunya adalah faktor masih relatif rendahnya insentif atau penghargaan atas karya penelitian oleh pemerintah hingga pada akhirnya kurang memicu peneliti dalam menghasilkan karya ilmiah yang inovatif. Pengaruh faktor relative rendahnya insentif tersebut terjadi juga pada peneliti yang menghasilkan varietas tanaman melalui pemuliaan tanaman.

${ }^{32}$ Pembangunan hukum yang dilakukan dengan melakukan perubahan terhadap ketentuan hukum yang sudah tidak layak dipergunakan lagi guna melindungi HKI tanaman merupakan bagian yang tidak terpisahkan dari tujuan pembangunan nasional yaitu mencapai manusia yang adil dan makmur termasuk hasil karya dari pemulia tanaman. Pemerintah atas nama kepentingan rakyat atau kepentingan negara berwenang melaksanakan HKI yang dilindungi oleh Undang-Undang HKI, dengan tetap memperhatikan kepentingan pemilik HKI. Subejo dalam tulisannya mengenai A New Trend of Agriculture Feminization memberikan pendapat yang intinya menyatakan bahwa Indonesia harus memberikan banyak perhatian pada penelitian dan pengembangan ${ }^{33}$,

32 Candra Irawan, Politik Hukum Hak Kekayaan Intelektual Indonesia "Kritik Terhadap WTO/TRIPs Agreement dan Upaya Membangun Hukum Kekayaan Intelektual Demi Kepentingan Nasional" (Bandung: Mandar Maju, 2011), halaman 269

${ }^{33}$ Subejo, Op.Cit., halaman 199 guna memberikan dampak yang signifikan terhadap pertumbuhan ekonomi nasional sehingga dapat bersaing dengan negara tetangga. Hasil pemuliaan tanaman berupa varietas unggul yang dilakukan oleh pemulia merupakan salah satu faktor yang mempengaruhi pertumbuhan ekonomi nasional melalui penelitian dan pengembangan bidang pertanian. Pemerintah tidak hanya meningkatkan hasil penelitian dan pengembangan bidang pertanian melalui produk varietas unggul saja akan tetapi juga memperhatikan atau memberikan perlindungan kepada pemulia sebagai penghasil varietas baru tanaman melalui pemberian royalti terutama bagi pemulia yang mengabdi pada lembaga penelitian dan pengembangan pertanian seperti Balitbangtan, Kementan.

Selain Pasal 8 UU PVT, telah diatur juga melalui Undang-Undang Nomor 18 Tahun 2002 tentang Sistem Nasional Penelitian, Pengembangan dan Penerapan Ilmu Pengetahuan dan Teknologi (UU Nomor 18 Tahun 2002) pada Pasal 16 ayat (3) dan Pasal 21 ayat (3), (4), dan (5). Pada Pasal 16 ayat (3) memberikan kepastian hukum bahwa badan penelitian dan pengembangan pemerintah berhak untuk memanfaatkan pendapatan yang diperoleh dari pengembangan penelitian termasuk hasil dari pemuliaan tanaman. Pada Pasal 21 ayat (3) memberikan kepastian hukum bahwa pemerintah berperan sangat penting dalam penyusunan kebijakan mengenai pemberian 
insentif terhadap hasil penelitian dan pengembangan pertanian yang dilakukan oleh pemulia tanaman berupa royalti hasil pemikirannya. Sehingga peningkatan perolehan hasil penelitian yang dilakukan oleh pemulia tanaman dapat diperoleh dan memberikan semangat bagi pemulia tanaman yang lain untuk menghasilkan varietas baru tanaman lain.

Ketentuan yang mendukung lainnya melalui Peraturan Pemerintah Nomor 20 Tahun 2005 tentang Alih Teknologi Kekayaan Intelektual Serta Hasil Kegiatan Penelitian dan Pengembangan Oleh Perguruan Tinggi dan Lembaga Penelitian dan Pengembangan (PP Nomor 20 Tahun 2005). Pasal-pasal yang memberikan kepastian hukum terhadap pemberian perlindungan hukum kepada pemulia tanaman dalam memperoleh royalti tertuang pada Pasal 5 ayat (1), Pasal 6 sampai dengan Pasal 11 dan Pasal 38 ayat (2b).

Pasal-pasal diatas yang terkandung dalam UU Nomor 18 Tahun 2002 dan PP Nomor 20 Tahun 2005 memberikan arti bahwa hasil dari penelitian dan pengembangan yang dilakukan oleh lembaga penelitian dan pengembangan pemerintah dengan menggunakan keseluruhan biaya dari negara merupakan milik pemerintah atau kepemilikan ada ditangan pemerintah, akan tetapi tetap memberikan pengakuan terhadap penemu pada bidang pertanian yaitu pemulia tanaman.
Pada pemberian lisensi varietas tanaman yang dilakukan oleh Balibangtan, Kementan dengan dunia usaha, kepemilikan hasil penelitian berada pada pemerintah melalui UK/UPT dengan tetap mencantumkan penemu varietas baru tanaman yaitu pemulia tanaman. Sehingga manfaat ekonomi dari pemberian lisensi varietas tanaman tersebut, tetap diperoleh oleh pemerintah (UK/UPT) dan pemulia tanaman. Perolehan royalti hasil pemberian lisensi varietas tanaman antara pemerintah (UK/UPT) dengan pemulia tanaman dilakukan sesuai dengan peraturan perundang-undangan yang berlaku dengan tetap mengedepankan prinsip adil, demokratis, transparan, dan akuntabel bagi para pihak.

Undang-Undang Nomor 18 Tahun 2002 dan PP Nomor 20 Tahun 2005 apabila diperhatikan merupakan upaya dalam mendorong perguruan tinggi dan lembaga penelitian dan pengembangan untuk dapat menggunakan pendapatan yang diperolehnya, serta secara bertahap menjadi mandiri dan tidak tergantung pada dukungan pembiayaan pemerintah.

34 Filosofi dari pemberian royalti sendiri adalah royalti diberikan kepada seseorang, bukan merupakan biaya untuk melaksanakan kembali suatu kegiatan, akan tetapi sebagai bentuk

\footnotetext{
34 Sabartua Tampubolon, Problematika Royalti HKI di Indonesia (Media HKI Vol. X/No. 4/Juli2013/humasristek),(http://www.ristek.go.id/ index.php/module/News), 06/12/2013
} 
penghargaan terhadap seseorang yang telah melaksanakan kegiatan penelitian dan menghasilkan karya intelektual. Berdasarkan hal tersebut, Peraturan Pemerintah tentang Tata Cara Penggunaan PNBP, tidak mencantumkan royalti sebagai salah satu bidang kegiatan yang dapat dibiayai dari sebagian dana PNBP. Adapun bidang-bidang kegiatan yang dapat dibiayai dari sebagian dana PNBP tersebut adalah: (a) penelitian dan pengembangan teknologi; (b) pelayanan kesehatan; (c) pendidikan dan Pelatihan; (d) penegakan hukum; (e) pelayanan yang melibatkan kemampuan intelektual tertentu; dan (f) pelestarian sumber daya alam. Kementerian Keuangan Republik Indonesia memang lebih menganjurkan Perguruan Tinggi (PT) dan lembaga penelitian dan pengembangan untuk membentuk BLU dibandingkan dengan unit kerja yang dimaksud dalam UU Nomor 18 Tahun 2002 dan PP Nomor 20 Tahun 2005. Pelaksanaan di lapangan selama ini, penggunaan dana yang diperoleh dari hasil alih teknologi oleh perguruan tinggi dan lembaga penelitian dan pengembangan mengalami masalah, karena apabila diperlakukan sebagai PNBP yang harus segera disetorkan ke kas negara, meskipun sebagian dapat dikembalikan ke lembaga yang bersangkutan, akan memperlambat proses pengembangan teknologi itu sendiri.

Perbedaan perspektif ini telah dicarikan solusi oleh pembuat UU
Nomor 18 Tahun 2002 dengan menyebutnya sebagai "lex specialis", sehingga perlakuannya harus dibedakan dari ketentuan terhadap keuangan secara umum. Akan tetapi ketentuan tersebut belum pernah diimplementasikan karena pengambil keputusan di bidang keuangan negara masih tetap berpandangan bahwa peneliti Indonesia yang mayoritas Pegawai Negeri Sipil (PNS) serta menggunakan anggaran publik dalam setiap kegiatannya, sehingga tidak diperkenankan untuk memperoleh pendapatan lain. 35 Permasalahan terhadap pemberian royalti bagi inventor termasuk pemulia tanaman yang mengabdi pada lembaga pemerintah juga dikemukakan oleh Ragil Yoga Edi dan Bambang Subiyanto yang intinya menyatakan bahwa penguasaan HKI oleh negara tercermin dalam ketentuan yang terdapat pada undang-undang HKI mengatur tentang hubungan antara pencipta/inventor dengan institusinya dan dikenal dengan istilah hubungan kedinasan. Pendapat yang dikemukakan oleh Ragil Yoga Edi dan Bambang

Subiyanto memberikan pemahaman bahwa pengaturan pemberian royalti bagi peneliti termasuk pemulia tanaman yang mengabdi pada lembaga penelitian dan pengembangan pemerintah belum

\footnotetext{
35 Ragil Yoga Edi dan Bambang Subiyanto, Analisi Kasus Terhambatnya Pemberian Royalti Kepada Inventor Atas Hasil Alih Teknologi Kegiatan Litbang, Makalah
} 
harmonis. Perundang-undangan yang terkait pemberian royalti masih perlu dilakukan harmonisasi dan sinkronisasi sehingga pelaksanaan pemberian royalti dapat dilaksanakan. Perundang-undangan mengenai pengaturan pemberian royalti selain berpedoman terhadap ketentuan hukum nasional harus juga berpedoman kepada ketentuan-ketentuan internasional mengenai HKI.

\section{PENUTUP.}

\section{C.1. Kesimpulan.}

1. Mekanisme pemberian lisensi pada produk varietas tanaman hasil pemuliaan tanaman di Indonesia:

a. Pada tahap pracontractual ini, pemberi lisensi melakukan perencanaan dengan mempertimbangkan kemampuan mitra/investor yang akan memanfaatkan varietas tanamannya dan penerima lisensi melakukan perencanaan terhadap keuntungan dari pemanfaatan varietas tanaman yang akan digunakan dalam kegiatan usahanya.

b. Pada tahap contractual ini, pemberi dan penerima lisensi melakukan persamaan kehendak diantara para pihak melalui klausul-klausul yang dicantumkan pada perjanjian lisensi varietas tanaman dengan mempertimbangkan keseimbangan hak dan kewajiban para pihak;

c. Pada tahap postcontractual ini, pemberi dan penerima lisensi melakukan pengawasan terhadap pelaksanaan perjanjian lisensi varietas tanaman berdasarkan isi perjanjian lisensi.

2. Hubungan hukum antara pemberi dan penerima lisensi pada produk varietas tanaman di Indonesia:

a. Pemulia tanaman hanya memiliki hubungan hukum atas kepemilikan hasil penelitian varietas tanamannya apabila belum memperoleh hak PVT;

b. Pemulia tanaman bukan sebagai pemegang hak PVT hanya memiliki hubungan hukum dengan pemegang hak PVT/pemberi lisensi dan tidak memiliki hubungan hukum kepada penerima lisensi.

3. Perlindungan hukum terhadap pemulia tanaman penghasil produk varietas tanaman sebagai pemberi lisensi:

a. Pemulia tanaman yang berasal dari lembaga penelitian dan pengembangan pemerintah belum terlindungi hak atas hasil penelitiannya;

b. Hak pemulia tanaman sebagai penemu varietas tanaman hanya sebatas pencantuman nama pemilik dalam sertifikat hak PVT;

c. Penghargaan berupa royalti 
kepada pemulia tanaman yang berasal dari lembaga penelitian dan pengembangan pemerintah masih terkendala dengan peraturan perundang-undangan.

\section{C.2. Saran.}

1. Mekanisme pemberian lisensi pada produk varietas tanaman hasil pemuliaan tanaman di Indonesia:

a. Pemerintah harus tegas dalam mengatur pemberian lisensi varietas tanaman hanya dapat dilakukan terhadap varietas tanaman yang telah memiliki hak PVT;

b. Ketentuan mengenai pihak yang membayar biaya pencatatan lisensi belum diatur dalam Undang-Undang, untuk itu ketentuan tersebut hendaknya dicantumkan dalam isi perjanjian lisensi;

c. Perlu adanya revisi terhadap PP Nomor 14 Tahun 2004 mengenai ketentuan pihak yang dikenakan kewajiban untuk membayar biaya pencatatan perjanjian lisensi;

2. Hubungan hukum antara pemberi dan penerima lisensi pada produk varietas tanaman di Indonesia:

a. Perjanjian lisensi yang sampai dengan saat ini belum dicatatkan pada Kantor PVT, harus segera dicatatkan agar mempunyai akibat hukum dengan pihak ketiga;

b. Perlu adanya harmonisasi dan sinkroninasi terkait pemberian lisensi dalam UU PVT dan Peraturan Pemerintah mengenai hak pemulia tanaman sebagai inventor kekayaan intelektual yang masih mempunyai hubungan hukum dengan varietas hasil invensinya.

3. Perlindungan hukum terhadap pemulia tanaman penghasil produk varietas tanaman sebagai pemberi lisensi:

a. Perlu adanya peranan pemerintah dalam kejelasan peroleh royalti bagi pemulia tanaman yang bekerja pada lembaga penelitian dan pengembangan pemerintah yang merasa dirugikan dengan peraturan perundang-undangan yang mewajibkan PNBP harus segera diserahkan ke Kas Negara sehingga pemulia tanaman (peneliti) tidak mendapatkan haknya;

b. Perlu segera diputuskan oleh pemerintah terkait pemanfaatan hasil perolehan royalti yang diterima lembaga penelitian dan pengembangan pemerintah guna memberikan hak pemulia tanaman berupa royalti dan juga meningkatkan hasil penelitian varietas tanaman. 
AFTAR

PUSTA

KA

\section{A. Buku}

Achmad Ali. 2011, Menguak Tabir

Hukum, Cet. 3; Penerbit Ghalia Indonesia: Bogor.

Astarini, Dwi Rezki Sri. 2013, Mediasi Pengadilan "Salah Satu Bentuk Penyelesaian Sengketa Berdasarkan Asas Peradilan Cepat, Sederhana, Biaya Ringan", Cet. 1; Penerbit PT. Alumni: Bandung.

Badan Penelitian dan Pengembangan Pertanian, Kementerian Pertanian. 2011, Petunjuk Teknis Kerjasama Alih Teknologi, Balai Pengelola Alih Teknologi Pertanian: Bogor.

Badrulzaman, Mariam Darus. 2005, Aneka Hukum Bisnis, Cet. 2; Penerbit PT. Alumni: Bandung.

$\begin{array}{ll}\text { Perdata Buku III } & \text { "Hukum } \\ \text { Perikatan } & \text { Dengan } \\ \text { Penjelasan”, Cet. 3; Penerbit } \\ \text { Alumni: Bandung. }\end{array}$

$\begin{array}{crr}\text { Departemen } & \text { Pertanian. } & 2010, \\ \text { Panduan } & \text { Umum } & \text { Alih } \\ \text { Teknologi } & \text { Dalam } & \text { Rangka } \\ \text { Inovasi } & \text { Hasil } & \text { Litbang }\end{array}$

Pertanian, Badan Penelitian dan Pengembangan Pertanian: Jakarta.

Djumhana, Muhammad, dan R. Djubaedillah. 2003, Hak Milik Intelektual, Sejarah. Teori dan Praktiknya di Indonesia, Penerbit Citra Aditya Bakti: Bandung.

Harahap, M. Yahya. 2006, Arbitrase, Cet. 4; Penerbit Sinar Grafika: Jakarta.

Hernoko, Agus Yudha. 2011, Hukum Perjanjian (Asas Proporsionalitas dalam Kontrak Komersial), Cet. 2; Penerbit Kencana Prenada Media Group: Jakarta.

Irawan, Candra. 2011, Politik Hukum Hak Kekayaan Intelektual Indonesia "Kritik Terhadap WTO/TRIPs Agreement dan Upaya Membangun Hukum Kekayaan Intelektual Demi Kepentingan Nasional", Cet. 1; Penerbit Mandar Maju: Bandung.

Kementerian Pertanian. 2012, Perkembangan Pengelolaan Hak Kekayaan Intelektual (HKI) dan Alih Teknologi Badan Litbang Pertanian, Badan Penelitian dan Pengembangan Pertanian: Jakarta. 
CV. Nuansa Aulia: Bandung.

Krisnawati, Andriana, dan Gazalba

Saleh. 2004, Perlindungan

Hukum Varietas Baru

Tanaman dalam Perspektif

Hak Paten dan Hak Pemulia,

Cet. 1; Penerbit PT.

RajaGrafindo Persada: Jakarta.

Lindsey, Tim, et al., 2011, Hak

Kekayaan Intelektual "Suatu

Pengantar", Cet. 6; Penerbit

Alumni: Bandung.

Lubis, Efridani. 2009, Perlindungan dan Pemanfaatan Sumber Daya Genetik "Berdasarkan Penerapan Konsep Sovereign Right dan Hak Kekayaan Intelektual", Cet. 1; Penerbit Alumni: Bandung.

Lukman, Mediya. 2013, Badan Layanan Umum Dari Birokrasi Menuju Korporasi, Cet. 1; Penerbit Bumi Aksara: Jakarta.

Makmur, Amrin. 1992, Pengantar Pemuliaan Tanaman, Penerbit Rineka Cipta: Jakarta.

Mangoendidjojo, W. 2007, Dasar-Dasar Pemuliaan Tanaman, Cet. 5; Penerbit Kanisius: Yogyakarta.

Margono, Suyud. 2010, Aspek Hukum Komersialisasi Aset Intelektual, Cet. 1, Penerbit

, 2011, Hak Milik Industri

"Pengaturan dan Praktik di

Indonesia", Cet. 1; Penerbit

Ghalia Indonesia: Bogor.

Marzuki, Peter Mahmud. 2005, Penelitian Hukum, Penerbit Kencana Prenada Media Group: Jakarta.

Mayana, Ranti Fauza. 2004, Perlindungan Desain Industri Di Indonesia (Dalam Era Perdagangan Bebas), Penerbit PT. Grasindo: Jakarta.

Miru, Ahmadi, dan Sakka Pati. 2012, Hukum Perikatan "Penjelasan Makna Pasal 1233 sampai 1456 BW, Cet. 2; Penerbit PT. Rajagrafindo Persada: Jakarta.

Mochtar, Dewi Astuty. 2001, Perjanjian Lisensi Alih Teknologi dalam Pengembangan Teknologi Indonesia, Cet. 1; Penerbit PT. Alumni: Bandung.

Muhammad, Abdulkadir. 2001, Kajian Hukum Hak Kekayaan Intelektual, Cet. 1; Penerbit PT. Citra Aditya Bakti: Bandung.

Muljadi, Kartini, dan Gunawan Widjaja. 2010, Seri Hukum Perikatan "Perikatan Yang 
Lahir dari Perjanjian”, Cet. 5; Penerbit PT. Rajagrafindo Persada: Jakarta.

Nina Nuraini, 2007, Perlindungan Hak Milik Intelektual Varietas Tanaman (Guna Peningkatan Daya Saing Agribisnis), Cet. 1; Penerbit Alfabeta: Bandung.

Purba, Achmad Zen. 2011, Perjanjian TRIPs dan Beberapa Isu Strategis, Cet. 1; Penerbit FHUI \& PT. Alumni: Bandung.

Purwaningsih, Endang. 2012, Hak Kekayaan Intelektual (HKI) dan Lisensi, Cet. 1; Penerbit CV. Mandar Maju: Bandung.

Riswandi, Budi Agus, dan Shabhi Mahmashani. 2009, Dinamika Hak Kekayaan Intelektual Dalam Masyarakat Kreatif, Cet. 1; Penerbit Total Media: Yogyakarta.

Saidin, OK. 2013, Aspek Hukum Hak Kekayaan Intelektual (Intellectual Property Rights), Cet. 8; Penerbit PT. RajaGrafindo Persada: Jakarta.

Salim HS., 2009, Pengantar Hukum Perdata Tertulis (BW), Cet. 6; Penerbit Sinar Grafika: Jakarta.

Sardjono, Agus. 2009, Membumikan
HKI di Indonesia, Cet. 1; Penerbit CV. Nuansa Aulia: Bandung.

Soetoprawiro, Koerniatmanto. 2013, Pengantar Hukum Pertanian, Cet. 1; Penerbit Gapperindo: Jakarta.

Subejo, 2013, Bunga Rampai Pembangunan Pertanian dan Pedesaan, Cet. 1; Penerbit Universitas Indonesia: Jakarta.

Subekti, 1996, Hukum Perjanjian, Cet. XVI; Penerbit Intermasa: Jakarta. Sudarmanto, 2012, KI \& HKI Serta Implementasinya Bagi Indonesia, Penerbit PT. Elex Media Komputindo: Jakarta.

Suhardo, Etty S. 2012, Hak Kekayaan Intelektual dan Lisensi HKI, Magister Ilmu Hukum Universitas Diponegoro: Semarang.

Sutedi, Adrian. 2013, Hak Atas Kekayaan Intelektual, Cet. 2; Penerbit Sinar Grafika: Jakarta.

$\begin{array}{crr}\text { Syukur, Muhammad, } & \text { Sriani } \\ \text { Sujiprihati } & \text { dan } & \text { Rahmi } \\ \text { Yunianti, } & \text { 2012, } & \text { Teknik } \\ \text { Pemuliaan } & \text { Tanaman, Cet. 1; } \\ \text { Penerbit } & \text { Penebar } & \text { Swadaya: } \\ \text { Jakarta. } & \end{array}$


Tampubolon, Sabartua. 2013, Politik

Hukum Iptek di Indonesia, Cet.

2; Penerbit Kepel Press:

Yogyakarta. Usman,

Rachmadi. 2003, Hukum Hak atas Kekayaan Intelektual

"Perlindungan dan Dimensi

Hukumnya di Indonesia”,

Cet.1; Penerbit Alumni:

Bandung.

Widjaja, Gunawan. 2003, Seri Hukum Bisnis "Lisensi", Cet. 2; Penerbit PT. RajaGrafindo Persada: Jakarta.

Yusdinal, 2008, Perlindungan Hukum Terhadap Lisensi Paten, Tesis; Universitas Diponegoro: Semarang.

\section{B. Artikel}

Edi, Ragil Yoga, dan Bambang Subiyanto, Analisi Kasus Terhambatnya Pemberian Royalti Kepada Inventor Atas Hasil Alih Teknologi Kegiatan Litbang, Makalah.

\section{Peraturan Perundang-Undangan}

Republik Indonesia. Undang-Undang Nomor 12 Tahun 1992 tentang Sistem Budidaya Tanaman.

Republik Indonesia. Undang-Undang Nomor 20 Tahun 1997 tentang Penerimaan Negara Bukan Pajak.
Republik Indonesia. Undang-Undang Nomor 29 Tahun 2000 tentang Perlindungan Varietas Tanaman.

Republik Indonesia. Undang-Undang Nomor 18 Tahun 2002 tentang Sistem Nasional Penelitian, Pengembangan dan Penerapan Ilmu Pengetahuan dan Teknologi.

Republik Indonesia. Undang-Undang Nomor 17 Tahun 2003 tentang Keuangan Negara.

Republik Indonesia. Undang-undang Nomor 1 Tahun 2004 tentang Perbendaharaan Negara. 